\title{
Effects of Urbanization on Bird Populations in the Canadian Central Arctic
}

\author{
RICHARD J. STANIFORTH ${ }^{1}$
}

(Received 4 July 2000; accepted in revised form 24 July 2001)

\begin{abstract}
Development of the Hamlet of Baker Lake (Qamani'tuaq) in the central Canadian Arctic during the 1950s was typical of the local urbanization that has occurred in Arctic regions during the latter half of the 20th century. The effects of urbanization on bird populations were examined by comparing populations before and after 1950, comparing populations in anthropogenic ecosystems with natural ones, and recording the presence or absence of exotic species usually associated with human dwellings and settlements. Of a total 60 local species, 21 had not been reported prior to 1950. Most of these were waterfowl, shorebirds, and gulls, all species that benefited from the presence of sewage lagoons and a refuse dump, or were associated with building sites (American robin). Semipalmated plovers were associated with gravel pits and gravel roadsides, whereas semipalmated sandpipers, Lapland longspurs, horned larks, Savannah sparrows, and white-crowned sparrows were most abundant in town. Vagrants from south of the tree line have been reported from the study site. It is hypothesized that climatic amelioration in association with the development of urban ecosystems may have encouraged migration overshoots in these species. These vagrants may be the early colonizers that eventually result in breeding range extensions, as has been observed in several waterfowl species, American robins, and white-throated sparrows. Twelve apparent species losses have occurred since 1950, but these are likely due to general scarcity or lack of observers rather than reduced abundance. No exotic "city" species, such as rock doves, European starlings, or house sparrows, have been recorded in Baker Lake. It is not anticipated that these species would become established or survive at Baker Lake in the near future, because of its isolation and severe winters.
\end{abstract}

Key words: birds, Nunavut, Northwest Territories, Baker Lake, urbanization, Arctic

RÉSUMÉ. Au cours des années 1950, l'aménagement du hameau de Baker Lake (Qamani'tuaq) dans le centre de l'Arctique canadien était typique de l'urbanisation locale qui a eu cours dans les régions arctiques durant la dernière moitié du XX' siècle. On a étudié les répercussions de l'urbanisation sur les populations d'oiseaux en comparant des populations avant et après 1950, en comparant des populations au sein d'écosystèmes anthropiques avec celles d'écosystèmes naturels, et en consignant la présence ou l'absence d'espèces exotiques associées aux habitations et aux établissements humains. Sur un total de 60 espèces locales, 21 n'avaient pas été rapportées avant 1950. Celles-ci étaient composées pour la plupart de sauvagine, d'oiseaux de rivage et de mouettes, espèces qui bénéficiaient toutes de la présence d'étangs d'eaux usées et d'une décharge, ou qui étaient associées avec des chantiers de construction (merle d'Amérique). Les pluviers semipalmés étaient associés aux gravières et aux bords de routes en gravier, alors que les bécasseaux semipalmés, les bruants lapons, les alouettes hausse-col, les bruants des prés et les bruants à couronne blanche se concentraient dans la ville. On a mentionné la présence sur le site de l'étude d'oiseaux égarés venus du sud de la limite des arbres. On émet l'hypothèse que le réchauffement climatique joint à l'expansion d'écosystèmes urbains pourrait avoir favorisé chez ces espèces le prolongement migratoire. Ces oiseaux égarés pourraient être les premiers à coloniser une région qui finit par devenir une extension de leur territoire de reproduction, comme on a pu l'observer chez diverses espèces de sauvagine ainsi que chez le merle d'Amérique et le bruant à gorge blanche. Depuis 1950, il semble s'être produit une perte pour douze espèces, mais cela est probablement dû à une pénurie générale d'observateurs plutôt qu'à une diminution de population. À Baker Lake, on n'a enregistré aucune espèce exotique «des villes», telles que le pigeon biset, l'étourneau sansonnet ou le moineau domestique. On ne s'attend pas à ce que ces espèces s'établissent ou survivent à Baker Lake dans un futur proche, en raison de l'isolation du lieu et de la rigueur de l'hiver.

Mots clés: oiseaux, Nunavut, Territoires du Nord-Ouest, Baker Lake, urbanisation, Arctique

Traduit pour la revue Arctic par Nésida Loyer.

\section{INTRODUCTION}

Human communities increased throughout the Arctic during the second half of the 20th century. Local urbanization of tundra landscapes has had a major and continuing impact on local avian populations, but there have been no accounts that monitored changes or described the new communities of birds that have adjusted to urban conditions. The development of the central Arctic Hamlet of Baker Lake, (Qamani'tuaq), Nunavut, Canada (64 $19^{\prime} \mathrm{N}$, $96^{\circ} 01^{\prime} \mathrm{W}$ ), mostly in the 1950 s and 1960 s, gave an opportunity to follow the influence of urbanization on the bird

${ }^{1}$ Department of Biology, University of Winnipeg, 515 Portage Avenue, Winnipeg, Manitoba R3B 2E9, Canada;

Richard.Staniforth@uwinnipeg.ca

(C) The Arctic Institute of North America 
populations that were present before the settlement and rapid development of that community. Baker Lake is located in the centre of the continental low Arctic tundra vegetation zone (see Bliss et al., 1981) and well away from direct climatic and biological influence of Hudson Bay and the Arctic Ocean. The Hamlet began with the settlement of previously scattered Inuit groups around a recently established RCMP post, churches, and a Hudson's Bay Company store. After 1950, the town grew rapidly: by 1998 , the population had grown to 1385 . Urbanization included the development of typical town infrastructure, such as buildings, roads, an airport, a sewage lagoon, refuse areas, gravel pits, and a source of water.

This study had three objectives: 1) to compare the status of bird populations before (as far as known) and after settlement in 1950;2) to compare the present abundance of species in anthropogenic and natural ecosystems; and 3) to note the occurrence of exotic species that are commonly associated with human settlement.

\section{STUDY AREA AND METHODS}

The study area is an $8 \times 12 \mathrm{~km}$ rectangle on the northwest shore of Baker Lake, Nunavut, Canada (Fig. 1). It extends from the inshore waters of Baker Lake to a maximum distance of $8 \mathrm{~km}$ inland, and from Paunraqtuuq Hill eastward to Prince River and Akilahaajuk Mountain. The study area includes Hornet Point, the Hamlet of Baker Lake, Nuvuttuaq Point, and Akilahaajuk Point. The topography features low hills that rise gently away from the lake to a height of about $70 \mathrm{~m}$ above sea level. The highest point is Paunraqtuuq Hill, at $129 \mathrm{~m}$ a.s.l. The Pre-Cambrian granite bedrock is exposed at higher elevations as outcrops or low cliffs (up to $20 \mathrm{~m}$ in height). Local surface substrates are peat deposits in poorly drained areas, or lacustrine and reworked glacial sediments elsewhere. The vegetation has been classified into five basic types of tundra according to differences in species composition, substrate, presence or absence of soil, and soil moisture content (Zoltai and Johnston, 1979; Scott, 1995).

Searches of historical bird records identified visitors who had observed birds and reported their occurrences in the vicinity of "Baker Lake Post" during the 20th century (Snyder, 1925; Douglas, 1928; Lloyd, 1928; CritchellBullock, 1931; Freuchen, 1937; Hørring, 1937; Clarke, 1940; Manning, 1948; Choque, 1956; McLaren and Holdsworth, 1978). References to birds were examined for precision of species identification and data on nesting, migration, and abundance. Care was taken to distinguish records for the settlement of Baker Lake from those for the vicinity of the lake of the same name.

During the present study, I visited Baker Lake in 1993 (11 - 13 August), 1994 (26 July - 1 August), 1995 (21-27 July), 1996 (10-24 July), 1997 (20 June-12 July), 1998 (6-16 July) and 1999 (28 June-19 July). I kept daily records of all bird species and the numbers of individuals, except on my arrival and departure days. Percent frequencies were calculated as the proportion of days that each bird species was seen, and notes were made of evidence that may have suggested nesting. Each species was categorized according to an abundance legend: "abundant" (observed on all visits to appropriate habitat, often in large numbers), "common" (observed on most visits to appropriate habitat, usually in small numbers), "uncommon" (infrequently observed in proper habitat), "rare" (seldom observed), or "accidental" (seldom observed and outside of expected range or habitat).

In a second study, I compared the present abundance of bird populations in anthropogenic ecosystems and natural ones. To do this, I made systematic observations by counting birds during time-limited hikes in specific ecosystems. The anthropogenic ecosystems of interest were the townsite, the refuse dump, and the sewage lagoon. The natural ecosystems included the shoreline and adjacent tundra from Paunraqtuuq Hill east to the Prince River. Data from the sewage lagoon and refuse dump were combined because the physical closeness of these adjacent ecosystems made it difficult to assess any discriminating habitat choice by the birds. Similarly, it was not practical to separate tundra from shoreline, as these two ecosystems did not have distinct boundaries. This study was carried out in 1997 (10 - 11 July), 1998 (8, 10, and 13 July), and 1999 (11 and 14 July).

To fulfill the third objective, I looked for typical "city" birds, such as rock doves, European starlings, and house sparrows, during the two surveys described above, paying special attention to habitats in which these species were likely to occur, e.g., the refuse dump, areas around bird feeders, sheltered eaves of dwellings, and backyards.

\section{RESULTS}

Table 1 lists the 60 bird species that have been reported in the literature for Baker Lake or were observed during the course of this study. The table allows a comparison of the abundance and breeding status (if known) of each species for the two time periods: a) the 50 years before settlement (1900-1950) and b) the 50 years since settlement (1950-2000) (this study and literature).

Twelve species apparently occurred between 1900 and 1950 that have not been reported since 1950: Pacific loon, yellow-billed loon, king eider, rough-legged hawk, merlin, whooping crane, red-necked phalarope, red phalarope, snowy owl, short-eared owl, common raven, and Brewer's blackbird. Detailed information is sparse for pre-1950 abundance and breeding status of most species on the above list. They were often merely reported as "present," thus making a direct comparison to abundance in the recent time period difficult.

Conversely, 21 species occurred after 1950 that had not been reported prior to that year: green-winged teal, northern pintail, greater scaup, common goldeneye, red-breasted 


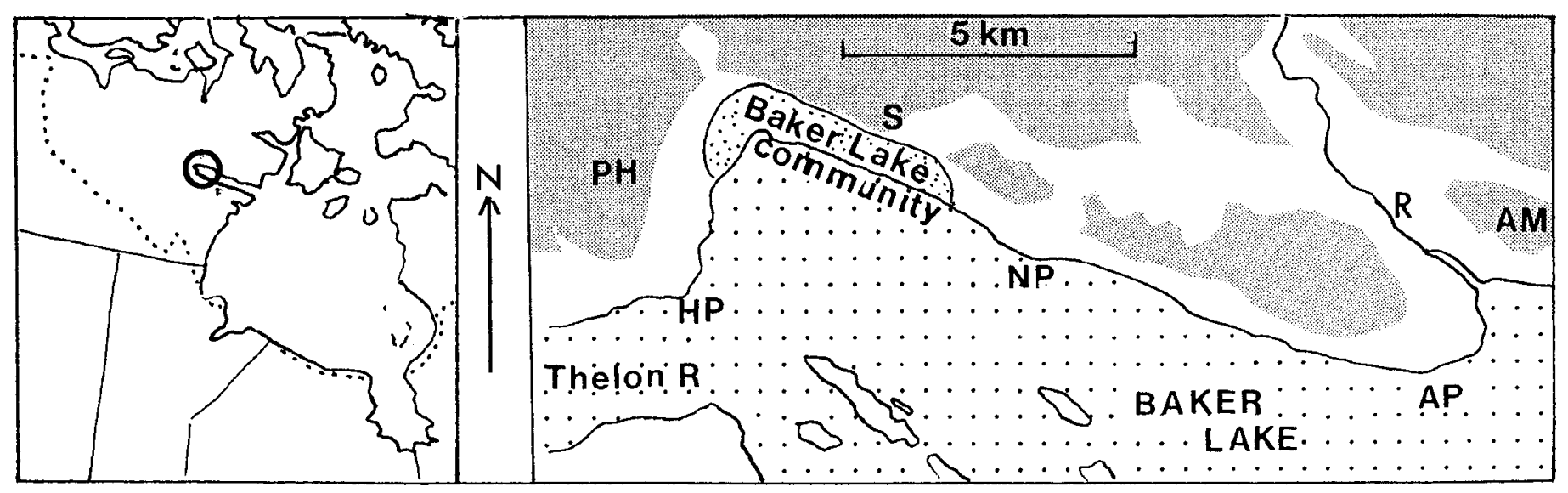

FIG. 1. Location and topography of the study site at Baker Lake $\left(64^{\circ} 19^{\prime} \mathrm{N}, 96^{\circ} 01^{\prime} \mathrm{W}\right)$, Nunavut, Canada. Place names mentioned in the text and abbreviated on the map are Paunraqtuuq Hill (PH), Hornet Point (HP), sewage lagoon and refuse dump (S), Nuvuttuaq Point (NP), Akilahaajuk Point (AP), Akilahaajuk Mountain (AM), and Prince River (R). Shading indicates land more than $50 \mathrm{~m}$ above sea level. The dotted line on the smaller map represents the tree line.

merganser, golden eagle, gyrfalcon, black-bellied plover, ruddy turnstone, sanderling, least sandpiper, white-rumped sandpiper, Thayer's gull, Iceland gull, glaucous gull, American robin, northern wheatear, yellow-rumped warbler, blackpoll warbler, Harris's sparrow, and whitecrowned sparrow. The waterfowl in this group are now all common breeding species, with the exception of the common goldeneye. Most of the shorebirds are also common now, either while on migration or as local breeders. New gull species have occasionally shown up at the refuse dump/sewage lagoons while on migration (Thayer's gull, Iceland gull), or as nonbreeding juveniles in summer (glaucous gull). The remaining species (raptors and passerines) are for the most part rarities or vagrants. However, there are two exceptions: white-crowned sparrows are now abundant and probably nesting; and a pair of American robins showed up in 1998 and again in 1999, when they attempted nesting.

Table 2 provides a comparison between birds in natural and anthropogenic ecosystems with respect to species richness and numbers of individuals seen per hour. Altogether, 1770 individuals of 36 species were encountered in the $37 \mathrm{~h}$ of the survey, giving an average observation rate of 49.2 birds per hour. Herring gulls and Lapland longspurs had the highest abundance values for any species encountered in this study, and their numbers represented almost $40 \%$ of all individuals observed.

The refuse dump-sewage lagoons had the largest numbers of waterfowl, herring gulls, and hoary redpolls, but the lowest diversity index. The town had fewest species, but many of these showed larger numbers here than in the other ecosystems, e.g., semipalmated sandpipers, horned larks, savannah sparrows, white-crowned sparrows, and Lapland longspurs. The natural ecosystems had the most species, but these exhibited relatively low, even levels of abundance. The result is that the natural ecosystems have the highest diversity index, even though no species was notably more abundant there than in the anthropogenic ecosystems.

\section{DISCUSSION}

\section{Changes in Abundance and Species Composition after Urbanization}

The rapid growth of the human population and urbanization of the landscape in the vicinity of Baker Lake since the early 1950s are expected to have caused major changes in the local bird fauna. Such changes are not easy to quantify. A systematic account of the pre-settlement bird fauna is not available for comparison with the present-day studies, even though several early, nonquantitative descriptions were published (e.g., Critchell-Bullock, 1931; Freuchen, 1937; Hørring, 1937; Clarke, 1940). Knowledge of the post-settlement avian fauna is limited to only two studies, i.e., McLaren and Holdsworth (1978) and the present study. There have been no Christmas Bird Counts since 1927 (Lloyd, 1928). Observations have been made during migration periods (Critchell-Bullock, 1931; McLaren and Holdsworth, 1978) and during the summer (Freuchen, 1937; this study) in both pre-settlement and post-settlement periods; however, there have been very few winter reports.

Twenty-one of the 60 species reported for Baker Lake had not been recorded prior to 1950 , but 11 of these were rare or accidental. The 10 remaining species are sufficiently abundant that it is unlikely that pre-1950 naturalists could have missed them if they had been present. These species are therefore assumed to be authentic new colonizers or regular visitors. They are green-winged teal, northern pintail, greater scaup, red-breasted merganser, black-bellied plover, ruddy turnstone, sanderling, least sandpiper, white-rumped sandpiper, and white-crowned sparrow. The duck species nest in the marsh that surrounds the sewage lagoons and raise their broods in its immediate vicinity. The new shorebirds were mostly attracted to shoreline sites during spring or autumn migration. The apparent recent increase in abundance and probable breeding of white-crowned sparrows in wet, bushy sites within 
TABLE 1. Pre- and post-settlement (1950) summer avifaunas around the central Arctic community of Baker Lake, Nunavut, Canada. Data are taken from the literature or the present study (see footnote).

\begin{tabular}{|c|c|c|}
\hline \multirow[b]{2}{*}{ Species } & \multicolumn{2}{|c|}{ Period } \\
\hline & Pre-settlement & Post-settlement \\
\hline Red-throated loon & present $^{4,6}$ & uncommon ${ }^{10}$ \\
\hline Pacific loon & present $4,5,6$ & - \\
\hline Common loon & present ${ }^{4}$ but identification? & rare $^{10}$ \\
\hline Yellow-billed loon & present $^{6}$ & - \\
\hline Tundra swan & present $^{4}$ & rare $^{10}$ \\
\hline Snow goose & present ${ }^{4,5}$; occasionally numerous ${ }^{6}$ & rare $^{10}$ \\
\hline Canada goose & present ${ }^{4}$, abundant ${ }^{6}$ & common, probably nesting ${ }^{10}$ \\
\hline Green-winged teal & - & abundant, nesting ${ }^{10}$ \\
\hline Northern pintail & - & abundant, nesting ${ }^{10}$ \\
\hline Greater scaup & - & abundant, nesting ${ }^{10}$ \\
\hline King eider & present $^{4,5,6}$ & - \\
\hline Long-tailed duck & often abundant $4,5,6$ & abundant, nesting ${ }^{10}$ \\
\hline Common goldeneye & - & rare $^{10}$ \\
\hline Red-breasted merganser & - & common, possibly nesting ${ }^{10}$ \\
\hline Rough-legged hawk & present ${ }^{4}$; occasionally nesting ${ }^{6}$ & - \\
\hline Golden eagle & - & rare $^{10}$ \\
\hline Merlin & present $^{6}$ & - \\
\hline Peregrine falcon & present $^{6}$ & uncommon, probably nesting ${ }^{10}$ \\
\hline Gyrfalcon & - & rare $^{10}$ \\
\hline Willow ptarmigan & nests ${ }^{4,5}$ & common, nesting ${ }^{10}$ \\
\hline Rock ptarmigan & nests 4,5 & $\operatorname{rare}^{10}$ \\
\hline Sandhill crane & numerous, nests ${ }^{5}$ & uncommon, probably nesting ${ }^{10}$ \\
\hline Whooping crane & accidental $^{6}$ & - \\
\hline Black-bellied plover & - & common spring migrant ${ }^{9}$ \\
\hline American golden-plover & present $^{5}$ & nesting ${ }^{9} ;$ common, nesting ${ }^{10}$ \\
\hline Semipalmated plover & present $^{5}$ & common, nesting ${ }^{10}$ \\
\hline Ruddy turnstone & - & common spring migrant ${ }^{9}$ \\
\hline Sanderling & - & common spring migrant $^{9} ;$ rare $^{10}$ \\
\hline Semipalmated sandpiper & present $^{5}$ & abundant, nesting ${ }^{10}$ \\
\hline Least sandpiper & - & common, nesting ${ }^{10}$ \\
\hline White-rumped sandpiper & - & common spring migrant ${ }^{9}$ \\
\hline Baird's sandpiper & common $^{3}$ & common spring migrant $^{9} ;$ rare, probably nesting ${ }^{10}$ \\
\hline Dunlin & present $^{5}$ & $\operatorname{rare}^{10}$ \\
\hline Red-necked phalarope & present $^{5}$ & - \\
\hline Red phalarope & present $^{5}$ & - \\
\hline Parasitic jaeger & present ${ }^{4,5}$ & common, possibly nesting ${ }^{10}$ \\
\hline Long-tailed jaeger & present $^{4}$ & uncommon, possibly nesting ${ }^{10}$ \\
\hline Herring gull & present $^{4}$ & abundant, possibly nesting ${ }^{10}$ \\
\hline Thayer's gull & - & rare spring migrant ${ }^{9}$ \\
\hline Iceland gull & - & uncommon spring migrant ${ }^{9}$ \\
\hline Glaucous gull & - & rare $^{10}$ \\
\hline Arctic tern & present $^{5}$ & $\operatorname{rare}^{10}$ \\
\hline Snowy owl & common ${ }^{4}$, numbers variable ${ }^{2}$ & - \\
\hline Short-eared owl & present $^{6}$ & - \\
\hline Horned lark & numerous, nesting ${ }^{5}$ & abundant, nesting ${ }^{10}$ \\
\hline Common raven & present $^{4}$ & - \\
\hline American robin & - & rare, nesting ${ }^{10}$ \\
\hline Northern wheatear & - & accidental $^{9}$ \\
\hline American pipit & numerous ${ }^{6}$ & common, probably nesting ${ }^{10}$ \\
\hline Yellow-rumped warbler & - & accidental $^{8}$ \\
\hline Blackpoll warbler & - & accidental $^{10}$ \\
\hline American tree sparrow & two individuals ${ }^{6}$ & rare, possibly nesting ${ }^{10}$ \\
\hline Savannah sparrow & present $^{6}$ & abundant, probably nesting ${ }^{10}$ \\
\hline Harris's sparrow & - & accidental $^{9}$ \\
\hline White-crowned sparrow & - & abundant, probably nesting ${ }^{10}$ \\
\hline Lapland longspur & abundant nester ${ }^{3,5,7}$ & common nester $^{9}$; abundant, nesting ${ }^{10}$ \\
\hline Brewer's blackbird & accidental $^{1}$ & - \\
\hline Snow bunting & common breeder $^{5}$; abundant migrant ${ }^{3}$ & uncommon, probably nesting ${ }^{10}$ \\
\hline Common redpoll & present $^{6}$ & uncommon in spring ${ }^{9}$; common, nesting ${ }^{10}$ \\
\hline Hoary redpoll & nesting 5 & absent in spring ${ }^{9} ;$ abundant, possibly nesting ${ }^{10}$ \\
\hline
\end{tabular}

References: ${ }^{1}$ Snyder (1925), ${ }^{2}$ Douglas (1928), ${ }^{3}$ Critchell-Bullock (1931), ${ }^{4}$ Freuchen (1937), ${ }^{5}$ Hørring (1937), ${ }^{6}$ Clarke (1940), ${ }^{7}$ Manning (1948), ${ }^{8}$ Choque (1955), ${ }^{9} \mathrm{McL}$ aren and Holdsworth (1978), ${ }^{10}$ this study.

the townsite is an interesting phenomenon, but difficult to explain. The breeding ranges of green-winged teal, greater scaup, and American robin showed significant northward extensions in comparison to 1986 maps (Godfrey, 1986). 
TABLE 2. Avifaunas of present-day natural and human-influenced habitats around the central Arctic community of Baker Lake, Nunavut, Canada. Values are the average numbers of individuals seen per hour.

\begin{tabular}{|c|c|c|c|}
\hline & \multirow{2}{*}{$\begin{array}{l}\text { Natural Habitat } \\
\text { Shore and tundra }\end{array}$} & \multicolumn{2}{|c|}{ Human-influenced Habitat } \\
\hline & & Townsite & Refuse dump and sewage lagoon \\
\hline Hours of observation & 15 & 8 & 14 \\
\hline \multicolumn{4}{|l|}{ Species: } \\
\hline Green-winged teal & - & - & 4.1 \\
\hline Northern pintail & 0.1 & 0.5 & 3.2 \\
\hline Greater scaup & - & - & 4.9 \\
\hline Long-tailed duck & 1.1 & _- & 1.4 \\
\hline Willow ptarmigan & 1.1 & 0.3 & 0.7 \\
\hline American golden-plover & 1.7 & - & 1.3 \\
\hline Semipalmated plover & 1.2 & 0.9 & 1.4 \\
\hline Sanderling & 1.1 & - & - \\
\hline Semipalmated sandpiper & 2.7 & 6.1 & 0.9 \\
\hline Herring gull & 1.7 & 4.8 & 15.9 \\
\hline Horned lark & 3.7 & 5.8 & 2.2 \\
\hline Savannah sparrow & 3.6 & 8.3 & 2.8 \\
\hline White-crowned sparrow & 2.3 & 7.4 & 0.9 \\
\hline Lapland longspur & 8.1 & 17.4 & 11.2 \\
\hline Common redpoll & 0.5 & 1 & 1.1 \\
\hline Hoary redpoll & 2.5 & 2.9 & 3.4 \\
\hline Total birds/hour & 34.3 & 56.8 & 57.2 \\
\hline Number of species ${ }^{1}$ & 21 & 16 & 20 \\
\hline Simpson's Diversity index $(D)$ & 11.09 & 6.5 & 6.01 \\
\hline
\end{tabular}

${ }^{1}$ Uncommon species ( $<1$ individual/ hour) that were omitted from the body of Table 2, but included in the totals: common loon, redthroated loon, common goldeneye, red-breasted merganser, golden eagle, peregrine falcon, gyrfalcon, rock ptarmigan, sandhill crane, least sandpiper, Baird's sandpiper, dunlin, parasitic jaeger, long-tailed jaeger, glaucous gull, Arctic tern, American robin, American pipit, blackpoll warbler, snow bunting.

Norment et al. (1999) noted northward extension of ranges in several species in the Thelon Game Sanctuary and attributed this phenomenon to a warming trend in the climate. Climate warming could also partially explain the changes in distributions of waterfowl and the whitecrowned sparrow observed at Baker Lake, but it is likely that the availability of anthropogenic ecosystems also played a significant role.

Observations of common goldeneye and blackpoll warbler near Baker Lake were farther north than expected (see Godfrey, 1986). These observations add to earlier records of other vagrants from south of the tree line: Brewer's blackbird (Snyder, 1925), yellow-rumped warbler (Choque, 1956), and Harris's sparrow (McLaren and Holdsworth, 1978). Perhaps these vagrants and other rare species are early pioneers of future northward range extensions related to a warming trend in the climate (see Norment et al., 1999). If this is so, then we may see them follow the trend shown by white-crowned sparrows, i.e., to form local, isolated population nuclei north of the tree line, some of which may occur near human habitations.

The apparent absence of 11 pre-settlement species after urbanization is probably an anomaly that perhaps should not be explained as a human-caused phenomenon. Most species on this list had been scarce before 1950 (e.g., Pacific loon, yellow-billed loon, king eider, merlin, whooping crane, red phalarope, red-necked phalarope, Brewer's blackbird), and there is the possibility that they have been overlooked in recent years. These species do not seem to be adversely affected by the occurrence of human populations. All have occurred in the vicinity of Churchill, Manitoba, where they have not shown marked decreases in numbers (Jehl and Smith, 1970; Chartier, 1994). A recent lack of observations in late fall and during winter may explain the apparent absences of four species: rough-legged hawk, snowy owl, short-eared owl, and common raven.

\section{Anthropogenic Ecosystems}

A key factor that has caused changes in the avifauna of Baker Lake has been the establishment of anthropogenic ecosystems. Certain species were identified more positively with human ecosystems than with natural sites. In particular, waterfowl (green-winged teal, northern pintail, greater scaup and, to a lesser extent, long-tailed duck) and herring gulls were much more abundant at the two nutrient-rich sewage lagoons and at the refuse dump than they were in natural ecosystems. Ample feather and bone evidence indicated that a pair of peregrine falcons, which probably nested on the cliffs adjacent to the lagoons in 1997 and 1998, ate ducks. The sewage lagoons provided a very localized but relatively species-rich ecosystem, which acted as a eutrophic oasis of algae and aquatic macrophytes and benefited birds at several trophic levels.

Within the townsite, species diversity was low, but large numbers of individuals represented most species. 
Semipalmated sandpipers, savannah sparrows, whitecrowned sparrows, and Lapland longspurs were all abundant, especially along the overgrown edges of ditches amongst the houses. Herring gulls were also always present, foraging for food along the shoreline of the hamlet, or even amongst the houses and around domestic refuse containers when there were no people about. Horned larks appear to come into the Hamlet to feed on grit and seeds. American robins nested in a pile of lumber at a building site. Gravel quarries on the eastern slope of Paunraqtuuq Hill and on the eastern edge of the hamlet were generally poor in birds, although semipalmated plovers were most frequent there.

\section{Characteristic Urban Species}

Characteristic urban species-rock dove, European starling, and house sparrow - are currently absent from Baker Lake. This may reflect the difficulty of dispersal of individuals to this isolated location or severity of climate rather than lack of appropriate habitat. All three species do occur at other northern locations, such as Churchill, Manitoba (Jehl and Smith, 1970; Chartier, 1994). At Churchill, introduction by humans (rock dove), colonization along the railway line from Thompson (house sparrow), and chance discovery (European starling) have been significant factors in the colonization process (Jehl and Smith, 1970). These colonization mechanisms are less likely for more remote sites such as Baker Lake. Even at Churchill, survival during the winter has been tenuous, with significant population fluctuations from year to year (Jehl and Smith, 1970). This further suggests that colonization of Baker Lake is unlikely, unless there is considerable amelioration in climate.

The Baker Lake region of Nunavut has an interesting avian fauna that is characteristic of the continental tundra vegetation zone. It shows elements of dry, damp, and wet tundra bird species, but generally the species richness is lower than in the better-documented coastal areas to the east and forests to the southwest (Höhn, 1968; Jehl and Smith, 1970). The effect of urban development at Baker Lake on bird populations in the last 50 years has been difficult to assess. However, anthropogenic ecosystems, such as the hamlet's sewage lagoons, refuse dump, gravel quarries, and housing sites, are developing distinctive avian faunas that do not include the more typical "city" birds of southern communities. The avian fauna of the nutrient-rich sewage lagoons is particularly interesting, because the algal blooms and vigorous growth of vascular plants support a locally unique, rich, and diverse community of waterfowl, which in turn form the diet of a nesting pair of peregrine falcons. Anthropogenic habitats, perhaps in association with climatic amelioration, are believed to have led to expansions in breeding ranges, new migration routes, or increases in abundance of several species not normally found north of the tree line.

\section{ACKNOWLEDGEMENTS}

I am indebted to Dr. J. Svoboda (Erindale College, University of Toronto) for introducing me to Baker Lake and making my research there a possibility. I wish to thank the Roman Catholic Mission at Baker Lake (Diocese of Churchill, Hudson Bay), and especially Bishop R. Rouleau, for logistical support. I am also grateful to Dr. C. Norment (State University of New York, Brockport) for offering advice on references, and to two anonymous referees for their supportive and constructive advice on an earlier draft of this manuscript. Travel to Nunavut was funded from a University of Winnipeg Research and Travel Grant.

\section{REFERENCES}

BLISS, L.C., HEAL, O.W., and MOORE, J.J. 1981. Tundra ecosystems: A comparative analysis. The International Biological Program Number 25. Cambridge: Cambridge University Press.

CHARTIER, B. 1994. A birder's guide to Churchill. Colorado Springs, Colorado: American Birding Association, Inc.

CHOQUE, C. 1956. Myrtle warbler at Baker Lake, N.W.T. Canadian Field-Naturalist 70:97.

CLARKE, C.H.D. 1940. A biological investigation of the Thelon Game Sanctuary. Bulletin 96. Biological Series 25. Ottawa: National Museum of Canada.

CRITCHELL-BULLOCK, J.C. 1931. An expedition to sub-arctic Canada, 1924-1925. Canadian Field-Naturalist 45:11-18.

DOUGLAS, W.O. 1928. Natural history notes from Baker Lake, N.W.T. Canadian Field-Naturalist 42:106.

FREUCHEN, P. 1937. Appendix III. Birds met with in the summer at Baker Lake. In: Report of the Fifth Thule Expedition. The Danish Expedition to Arctic North America in charge of Knud Rasmussen. Copenhagen: Gyldenalske Boghandel Nordisk Forlag.

GODFREY, W.E. 1986. The birds of Canada. Rev. ed. Bulletin 203. Biological series 73. Ottawa: National Museums of Canada.

HÖHN, E.O. 1968. The birds of Chesterfield Inlet, District of Keewatin, N.W.T., Canada. Canadian Field-Naturalist 28: 244-262.

HØRRING, R. 1937. Report of the Fifth Thule Expedition 19211924. Zoology II. Birds collected on the Fifth Thule Expedition. In: Report of the Fifth Thule Expedition. The Danish Expedition to Arctic North America in charge of Knud Rasmussen. Copenhagen: Gyldenalske Boghandel Nordisk Forlag.

JEHL, J.R., and SMITH, B.A. 1970. Birds of the Churchill Region, Manitoba. Special Publication No. 1. Winnipeg: Manitoba Museum of Man and Nature.

LLOYD, H. 1928. 1927 Christmas bird count: Northwest TerritoriesBaker Lake. Canadian Field-Naturalist 42:102.

MANNING, T.H. 1948. Notes on the country, birds and mammals west of Hudson Bay between Reindeer and Baker Lakes. Canadian Field-Naturalist 62:1-28.

McLAREN, P.L., and HOLDSWORTH, C. 1978. Summer bird populations in the Pilz Lake-Baker Lake area, District of Keewatin, N.W.T. Unpubl. ms. prepared for the Environmental Program of the Polar Gas Project. Available at LGL Limited 
Environmental Research Associates, Box 280, 22 Fisher St., King City, Ontario L7B 1A6.

NORMENT, C.J., HALL, A., and HENDRICKS, P. 1999. Important bird and mammal records in the Thelon River Valley, Northwest Territories: Range expansions and possible causes. Canadian Field-Naturalist 113:375-385.

SCOTT, G.A.J. 1995. Canada's vegetation: A world perspective. Montreal: McGill-Queen's University Press.
SNYDER, L.L. 1925. A distributional record for Brewer's blackbird (Euphagus cyanocephalus). Canadian Field-Naturalist 39:63.

ZOLTAI, S.C., and JOHNSON, J.D. 1979. Vegetation-soil relationships in the Keewatin District. ESCOM (European Software Control and Metrics) Report, numbers 1-25. Ottawa: Fisheries and Environment Canada. 